\title{
Revising EAP Programs in Indonesia: Where to Go?
}

\author{
Imroatus Solikhah \\ State Islamic Institute of Surakarta \\ imroatus77iim@gmail.com
}

\begin{abstract}
This study examines how English for Academic Purposes programs are implemented in Indonesia. It reveals indications pointing to low standards in EAP implementations. This study describes EAP practices in three Indonesian universities: The State Islamic University, the State University, and the private University of Surakarta. Policy makers, lecturers, and students were involved through interviews, and classroom observations were conducted on a grounded theory basis. The results reveal how universities roll out EAP programs as study skills but fail to perform a student-based needs analysis and determine the learning outcomes in the areas of academic literacy and English proficiency in oral and written forms. Logistic problems also adversely affect the standard of curriculum contents, teaching materials, and teaching techniques. Indeed, many rely on a 2 or 4 credit General English Course, whereas EAP needs to go further to achieve a TOEFL PBT score of at least 450 or TOEFL iBT test, which only goes up to 120 as an indicator of success.
\end{abstract}

Keywords: renewal, EAP, study skills, general English, teaching materials, needs analysis.

\section{INTRODUCTION}

This study sheds light on the state of English for Academic Purposes (EAP) programs in Indonesia compared with the international standard. EAP programs in Indonesia mostly rely on general English teaching [1], especially the English for General Basic Skill Course (MKDU). The typical EAP course has four characteristics: it has no definite needs analysis of students, it is grammar and reading oriented, it uses teacher-made material, and it is oriented toward TOEFL scores [2]. There is also often no provision for academic writing and reading [3].

The practice of EAP in Indonesia faces some challenges. EAP programs in Indonesia do not support the academic success of overseas studies [4], nor do they serve as a "tertiary level English instructional training to improve language proficiency" [5]. EAP programs in Indonesia also lack of the standardized courses necessary to acquire the skills needed to function successfully in academic settings [6]. EAP pedagogy needs to address the requirements of learners from many different countries, so the content of EAP courses, as well as the materials development and syllabus design, are determined by students' current command of English [6].
The duration of EAP courses also varies, so they can be pre-sessional (i.e., a full-time course scheduled before an academic course begins) or in-sessional (i.e., a course delivered during the academic semester, so students take them in parallel with their major courses). Course durations can vary from a short 4-12 weeks to 6-12 months or longer [7].

Tribble [8] asserts that the curricula of EAP courses need to be academic oriented and presuppose solid literacy abilities. They build upon students' knowledge of a particular language by teaching certain ways of talking, reading, and writing about ideas and texts. A major challenge faced by learners is not conversational fluency but rather academic literacy [9]. Academic literacy is defined as covering reading, writing, speaking, listening, and thinking skills, as well as the dispositions and mental habits, that students need for academic success. The areas of academic literacy needed for success in university learning are essentially proficiency in writing and reading [10]. In Asian countries, challenges appear in the form of inadequate study skills [11], such as when listening to lectures, talks, or seminars; participating in tutorials and discussions; working under supervision; conducting practical and laboratory work; engaging in fieldwork and private study; reading reference material, and so on. Drawing on the background of EAP, the following research questions guide this study:

How are EAP programs in Indonesian universities implemented with regards to the international standard?

How is academic literacy designed in the needs analysis of EAP programs for Indonesian universities?

How can EAP syllabi be revisited to address the shortcomings of EAP programs in Indonesian universities?

\section{METHOD}

This study evaluates various materials reporting on the practices of EAP. These include five articles from international journals, three theses, and four doctorate dissertations written by Indonesian university graduates. Content analysis and grounded theory were applied for the evaluation. Three universities were selected as subjects for the study, namely the State Islamic Institute (IAIN) of Surakarta, Sebelas Maret Unversity (UNS), and Veteran Bangun Nusantara University (Univet). This study used purposive sampling to recruit the participants who were deemed information-rich cases [12] and who offered the best opportunity to "understand the central phenomenon" [13]. Five lecturers were selected from each of the three universities for a total of 15 , while 10 
students of EAP courses were chosen from each of the three universities for a total of 30 .

A semi-structured interview was employed to collect data. Free body [14] argues that semi-structured interviews give participants the opportunity to answer the posed questioned fully. Two different interview guides were prepared for the staff and student participants. The interview questions for students were designed to focus on their general attitudes and their own experiences of EAP. The interview questions for lecturers, meanwhile, were structured around their general attitudes, teaching goals, and preparations for serving EAP courses. The interviews were audio recorded, so they could be rechecked for accuracy. The data were analysed through an inductive approach where transcription and coding helped to identify themes [13]. The researcher identified themes according to keywords, phrases, and sentences used in answers to the questions, which were then categorized into different themes formed during the analysis of interview data.

\section{RESULTS AND DISCUSSION}

\section{EAP Practices in Indonesia}

Table 1 shows the status of EAP in the Indonesian context with reference to the decree of the Ministry of Higher Education No. 011/2000.

Table 1. Status of English courses for EAP practices in Indonesia

\begin{tabular}{|c|c|c|c|}
\hline No & Status & Credit/Objectives & Course Contents \\
\hline \multirow[t]{3}{*}{1} & MKDU & a. $2-4$ credits over 2 semesters & a. Grammar \\
\hline & & f all departments except English & b. Genre-based reading \\
\hline & & $\begin{array}{l}\text { c. Requisite to complete } 140 \\
\text { undergraduate course credit }\end{array}$ & c. Exercises on grammar \& reading \\
\hline \multirow[t]{3}{*}{2} & EAPCERT & a. $2-4$ credits ( 24 to 32 meetings) & a. TOEFL preparation \\
\hline & & $\begin{array}{l}\text { b. TOEFL or English Proficiency Test } \\
\text { (EPT) }\end{array}$ & b. EPT preparation \\
\hline & & $\begin{array}{l}\text { c. Certificate for leaving exam } \\
\text { d. Admits last semester's students of all } \\
\text { departments, including English }\end{array}$ & $\begin{array}{l}\text { c. Grammar, vocabulary, reading, listening } \\
\text { d. Drills on TOEFL tests }\end{array}$ \\
\hline \multirow[t]{2}{*}{3} & $\begin{array}{l}\text { ESP } \\
\text { COURSE }\end{array}$ & $\begin{array}{l}\text { a. Two credits per semester for senior } \\
\text { students of the English/Literature } \\
\text { department }\end{array}$ & a. Developing ESP syllabus \\
\hline & & b. Equipping ESP or EAP design & b. Submitting the syllabus \\
\hline \multirow[t]{3}{*}{4} & $\begin{array}{l}\text { EAP } \\
\text { PUBLIC }\end{array}$ & $\begin{array}{l}\text { a. } 18-32 \text { weeks for members of the public, } \\
\text { including students }\end{array}$ & a. Preparation on TOEFL/EPT \\
\hline & & $\begin{array}{l}\text { b. Training on TOEFL, TOEIC, speaking } \\
\text { skills, etc. }\end{array}$ & $\begin{array}{l}\text { b.Analysis of grammar and reading } \\
\text { passages of TOEFL tests }\end{array}$ \\
\hline & & $\begin{array}{l}\text { c. Focused on the specific needs of learners } \\
\text { d. Certificate of TOEFL, IELTS, or specific } \\
\text { need }\end{array}$ & $\begin{array}{l}\text { c. Drills on listening tests } \\
\text { d.Drills on speaking or writing for } \\
\text { academic purposes as per students' needs }\end{array}$ \\
\hline
\end{tabular}

Table 1 suggests that English courses fall into four categories: English as MKDU, English as an EAP certificate, English as an ESP/EAP Course, and English as an EAP course for the public. The MKDU course is required to complete the minimum of 140 credits for undergraduate students. English as an EAP certificate, meanwhile, aims for certification through a TOEFL test as the final examination. English as an ESP or EAP course is a mandatory course for students majoring in English literature or the teaching of English. The purpose is to equip students, who are generally EFL learners, to attain the theoretical and practical notions of ESP or EAP. Finally, EAP for the public aims to improve learners' competencies in English, such as in the areas of the international TOEFL and TOEIC tests, academic writing, and professional and academic speaking. These courses are offered to the public, but students may also participate.

\section{Academic Literacy Implementation}

The results of the interviews and checklists indicated the needs analysis for English teaching. This included a basic knowledge of grammar and a reasonable vocabulary, as well as speaking, listening, reading, and writing skills. When students were asked to check the most important items they expected to be included in an EAP course's content, they mostly selected general English grammar, vocabulary, conversation, and reading skills. Writing and listening are considered harder skills to acquire, and students placed them in the lower range of their needs. As can be seen in Table 2, vocabulary and grammar - as well as listening, speaking, reading, and writing in English - are perceived as problematic by at least $60 \%$ of students, implying that many are limited in both their spoken and written English skills. 
Table 2. The expected subject needs for an EAP course

\begin{tabular}{lllccc}
\hline \multirow{2}{*}{ No Subject } & & \multicolumn{2}{c}{ Teachers } & \multicolumn{2}{c}{ Students } \\
\cline { 3 - 6 } & & & $\mathrm{F}$ & $\mathrm{F}$ & $\%$ \\
\hline 1 & Basic grammar & 10 & 100 & 30 & 100 \\
2 & Academic grammar & 9 & 90 & 25 & 83.3 \\
3 & General vocabulary: 3,000-4,000 words & 6 & 60 & 28 & 93.3 \\
4 & Academic vocabulary:750 words & 8 & 80 & 10 & 33.3 \\
5 & Conversation & 8 & 80 & 30 & 100 \\
6 & Public speaking & 9 & 90 & 25 & 83.3 \\
7 & Academic speaking & 10 & 100 & 30 & 100 \\
8 & Listening for general use & 6 & 60 & 30 & 100 \\
9 & Listening for TOEFL & 8 & 80 & 20 & 66.7 \\
10 & Reading for daily needs & 10 & 100 & 30 & 100 \\
11 & Reading for academic texts & 10 & 100 & 20 & 66.7 \\
12 & Academic reading & 10 & 100 & 20 & 66.7 \\
13 & Writing for daily uses & 8 & 80 & 30 & 100 \\
14 & Academic writing & 10 & 100 & 25 & 83.3 \\
\hline
\end{tabular}

\section{Modified EAP Syllabus}

Prior to the syllabus design development, problems were identified that were inhibiting the success of instruction. The revised teaching objectives were then formulated, as shown in Table 3. The modified teaching objectives rely on the existence and inclusion of academic literacy. Literacy in this context refers to a mastery of basic grammar and a vocabulary of 3,000 words or more. Students admit that their academic literacy provision should begin with academic writing, academic speaking, and academic reading. Academic listening, meanwhile, is considered a skill that comes later, so they did not include it as a top priority. The syllabus design of EAP is shown in Table 4. It accommodates revised objectives for the teaching of literacy areas, academic literacy, and other subject matters that students and teachers consider important to include in the context of EFL and ELFA (English as a lingua franca in academic settings).

Table 3. Revised subject matters and program objectives

\begin{tabular}{|c|c|c|}
\hline No & Subject & Objectives \\
\hline 1 & Grammar & $\begin{array}{l}\text { To achieve grammar literacy and grammar proficiency } \\
\text { a. Basic grammar } \\
\text { b. Intermediate grammar } \\
\text { c. Advanced and academic grammar }\end{array}$ \\
\hline 2 & Vocabulary & $\begin{array}{l}\text { To achieve vocabulary knowledge and learn academic vocabulary } \\
\text { a. Basic vocabulary: } 1,000 \text { to } 3,000 \text { words } \\
\text { b. Advanced vocabulary: } 4,000+\text { words } \\
\text { c. Academic vocabulary }\end{array}$ \\
\hline 3 & Listening & $\begin{array}{l}\text { To attain academic literacy in listening tests and academic discourse delivered in English } \\
\text { a. To drill listening skills for TOEFL or other English tests } \\
\text { b. To listen and understand spoken discourses } \\
\text { c. To paraphrase ideas from a spoken text }\end{array}$ \\
\hline 4 & Speaking & $\begin{array}{l}\text { To accomplish academic literacy for orals presentations in academic settings addressed in English } \\
\text { a. To give talks in formal and informal settings } \\
\text { b. To present topics for academic settings } \\
\text { c. To summarize and conclude a spoken or written discourse }\end{array}$ \\
\hline 5 & Reading & $\begin{array}{l}\text { To gain academic literacy for reading academic texts and other academic documents } \\
\text { a. To read and critically evaluate academic texts } \\
\text { b. To survey reading resources } \\
\text { c. To summarize or paraphrase academic texts }\end{array}$ \\
\hline 6 & Writing & $\begin{array}{l}\text { To achieve literacy in writing for academic purposes in academic settings } \\
\text { a. To write an academic composition } \\
\text { b. To write expository and argumentative essays } \\
\text { c. To develop the details of an essay with appropriate techniques } \\
\text { d. To use statistics, facts, citations, and quotations }\end{array}$ \\
\hline
\end{tabular}


Table 4. Needs Analysis for EAP (Modified from Solikhah, 2014)

\begin{tabular}{|c|l|l|}
\hline No & \multicolumn{1}{|c|}{ Component } & \multicolumn{1}{c|}{ Description } \\
\hline 1 & Learning Outcomes & $\begin{array}{l}\text { Demonstrating academic literacy through writing, speaking, reading, and listening skills, } \\
\text { inducing a 3,000 words vocabulary and an academic vocabulary for various academic } \\
\text { contexts. }\end{array}$ \\
\hline 2 & Literacy & Academic grammar and academic vocabulary \\
\hline 3 & Academic literacy & Academic writing, academic speaking, and academic reading \\
\hline 4 & Objectives & 1. To achieve English literacy in the areas of grammar and vocabulary \\
& & 2. To achieve literal, inferential, and critical reading comprehension skills \\
& & 3. To achieve writing skills for academic contexts \\
& & 4. To achieve speaking skills for academic settings \\
& & 5. To achieve listening skills for academic settings \\
\hline 5 & Contents \& Organization & 1. General vocabulary: 3,000-4,000 words \\
& & 2. Academic vocabulary \\
& & 3. Basic grammar and academic grammar \\
& & 4. Academic writing: paragraphs, composition, and essays \\
& & 5. Speaking for academic \& ELFA settings \\
& & 6. Reading skills for literal, inferential, critical comprehension \\
\hline 6 & Methodology & Study skills, task-based approaches, competency-based teaching, genre-based teaching \\
\hline 7 & Learners Target & Freshmen (semesters 1 and 2) of a university majoring in a non-English department \\
\hline 8 & Duration & 4-8 credits with 32 x 2 = 64 meetings \\
\hline
\end{tabular}

\section{CONCLUSION AND IMPLICATION}

In summary, EAP practices in Indonesian universities rely on practical perspectives to fulfil undergraduate credits. EAP courses are typically designed in one of four formats: as a general English course, a requisite for a leaving exam, a course aiming toward an EAP certificate, and an EAP course offered to the public. The management of each faculty sets the study program, and the quality standard for EAP courses is not clearly defined. They often ignore the inclusion of academic literacy, making students literate in basic English only, and a needs analysis is not used when developing teaching materials and learning outcomes. This study has therefore modified the EAP syllabi to accommodate the needs of students with academic literacy and teaching materials based on the international standard.

This study has its limitations, however, such as the small sample used for investigation. This may affect the depths of the findings, and some details for the needs are not included. Future research is suggested to improve the instruments used and help elaborate on the needs of students in detail. Universities are also encouraged to set up EAP courses as professional units and collaborate with foreign universities to meet the international standard.

\section{REFERENCES}

[1] Solikhah, Imroatus. English for Academic Voices: A Survey on Practices and Challenges in the State Universities of Central Java, Indonesia. International Journal of Academic Research, 5(4): 121-125. DOI: 10.7813/2075-4124.2013/54/B.17. (2013).

[2] Solikhah, Imroatus; Nurkamto, Joko; Waluyo, Herman J, \& Slamet, St. Y. A competency-EAP textbook for the learners of non-English program (Research and Development at State Universities in Central Java and DIY, Indonesia). Journal of Language and Literature, 5(3): 301-307. DOI: 10.7813/j11.2014/5-3/51. (2014).
[3] Solikhah, Imroatus. Designing Academic Literacy Framework of EAP Programs for Indonesian Learners. Journal of Language and Literature, 6(2): 32-37. DOI: 10.7813/j11.2015/6-2/5. (2015).

[4] Hyland, K. English for Academic purposes: An advanced resource book. London: Routledge.

[5] Hadley, G. (2015). English for academic purposes in Neoliberal Universities: A critical grounded theory. London and New York: Springer. (2006).

[6] Szudarski, P; Carter, R \& Adolphs. EAP Domain: Review Document. Netherlands: University of Nottingham. (2012).

[7] Hyland, K. \& Hamp-Lyons, L. Issues and directions. Journal of English for Academic Purposes. 1, 1-12. (2002).

[8] Tribble, Christopher. ELFA Vs. Genre: A New Paradigm War in EAP Writing. Journal of English for Academic Purposes, 25(2): 30-44. (2017).

[9] Warchauer, Mark, et al. Promoting Academic Literacy with Technology: Successful Laptop Programs in K-12 Schools. System, 32: 525-577. DOI:10.1016/j.system.2004,09.010. (2004).

[10] Mo, H. A Brief Review of English for Academic Purposes (EAP). US-China Foreign Language, 3(7): 62-67. (2005).

[11] Ting, Mao. Challenges of English for Academic Purposes in Asia. Journal of Foreign Language Education and Technology, Vol. 2 No. 2, pp. 3653. (2017).

[12] Hsieh, H.-F., \& Shannon, S.E. Three approaches to qualitative content analysis. Qualitative Health Research, 15(9): 1277-1288.(2005)

[13] Creswell, J. W. Educational research: Planning, conducting, and evaluating quantitative and qualitative research (4th ed.). Boston, MA: Pearson Education Inc. (2012).

[14] Freebody, P. Qualitative research in education: interaction and practice. London: SAGE Publications. (2003). 